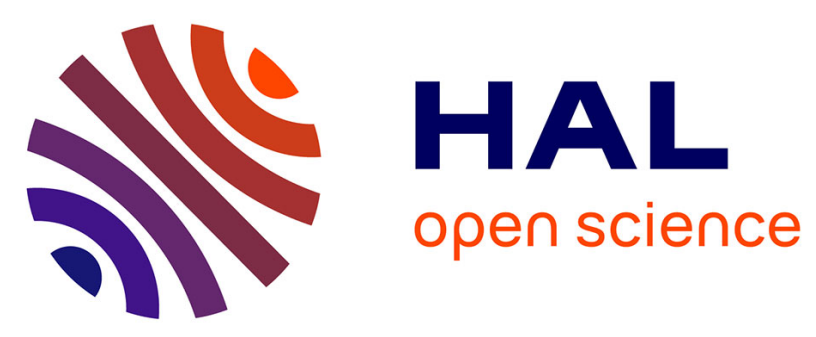

\title{
Measurement in a wind tunnel of dry deposition velocities of submicron aerosol with associated turbulence onto rough and smooth urban surfaces
}

Pierre Roupsard, Muriel Amielh, Didier Maro, Alexis Coppalle, Hubert Branger, Olivier Connan, P. Laguionie, D. Hébert, M. Talbaut

\section{To cite this version:}

Pierre Roupsard, Muriel Amielh, Didier Maro, Alexis Coppalle, Hubert Branger, et al.. Measurement in a wind tunnel of dry deposition velocities of submicron aerosol with associated turbulence onto rough and smooth urban surfaces. Journal of Aerosol Science, 2013, 55, pp.12-24. 10.1016/j.jaerosci.2012.07.006 . hal-00760178

\section{HAL Id: hal-00760178 https://hal.science/hal-00760178}

Submitted on 4 Dec 2012

HAL is a multi-disciplinary open access archive for the deposit and dissemination of scientific research documents, whether they are published or not. The documents may come from teaching and research institutions in France or abroad, or from public or private research centers.
L'archive ouverte pluridisciplinaire HAL, est destinée au dépôt et à la diffusion de documents scientifiques de niveau recherche, publiés ou non, émanant des établissements d'enseignement et de recherche français ou étrangers, des laboratoires publics ou privés. 


\section{Elsevier Editorial System(tm) for Journal of Aerosol Science Manuscript Draft}

Manuscript Number:

Title: MEASUREMENT IN A WIND TUNNEL OF DRY DEPOSITION VELOCITIES OF SUBMICRON AEROSOL WITH ASSOCIATED TURBULENCE ONTO ROUGH AND SMOOTH URBAN SURFACES

Article Type: Regular Paper

Keywords: dry deposition; deposition velocity; submicron aerosol; urban surfaces; wind tunnel Corresponding Author: Mr. Pierre Roupsard, M.D.

Corresponding Author's Institution: IRSN

First Author: Pierre Roupsard, M.D.

Order of Authors: Pierre Roupsard, M.D.; Muriel Amielh, PhD; Denis Maro, Professor; Alexis Coppalle, Professor; Hubert Branger, PhD; Olivier Connan, PhD; Philippe Laguionie, PhD; Didier Hébert; Martine Talbaut, PhD 
Please find as attached files a manuscript untitled:

"Measurement in a wind tunnel of dry deposition velocities of submicron aerosol with associated turbulence onto rough and smooth urban surfaces", co-authored by : P. Roupsard, M. Amielh, D. Maro, A. Coppalle, H. Branger, O. Connan, P. Laguionie, D. Hébert and M. Talbaut; for submission to "Journal of Aerosol Science".

Best regards.

Pierre Roupsard 


\section{HIGHLIGHTS:}

2 Submicron aerosol deposition on urban surfaces is studied in a wind tunnel.

3 Associated turbulent parameters are measured or estimated with a hot wire anemometry.

$4 \quad$ Settling has an influence on deposition on smooth surface and at low wind speed.

5 Submicron aerosol deposition is dependent on turbulent deposition processes. 
1 MEASUREMENT IN A WIND TUNNEL OF DRY DEPOSITION VELOCITIES OF SUBMICRON 2 AEROSOL WITH ASSOCIATED TURBULENCE ONTO ROUGH AND SMOOTH URBAN SURFACES

3 P. Roupsard ${ }^{1 *}$, M. Amielh ${ }^{2}$, D. Maro ${ }^{1}$, A. Coppalle ${ }^{3}$, H. Branger ${ }^{2}$, O. Connan ${ }^{1}$, P. Laguionie ${ }^{1}$, D. Hébert $^{1}$ 4 and M. Talbaut ${ }^{3}$.

5

$6{ }^{1}$ Laboratoire de Radioécologie de Cherbourg-Octeville (LRC), Institut de Radioprotection et de Sûreté $7 \quad$ Nucléaire (IRSN), 50130 Cherbourg-Octeville, France.

$8 \quad$ pierre.roupsard@irsn.fr; denis.maro@irsn.fr; olivier.connan@irsn.fr; philippe.laguionie@irsn.fr;

9 didier.hebert@irsn.fr

$10{ }^{2}$ Institut de Recherche sur les Phénomènes Hors Equilibre (IRPHE), CNRS, UMR-7342, 13384 Marseille,

11 France.

12 amielh@irphe.univ-mrs.fr; branger@irphe.univ-mrs.fr

$13{ }^{3}$ Complexe de Recherche Interprofessionnel en Aérothermochimie (CORIA), UMR-6614, 76801 Saint14 Etienne du Rouvray, France. alexis.coppalle@coria.fr; martine.talbaut@coria.fr

*CORRESPONDING AUTHOR: pierre.roupsard@irsn.fr

Tel +33233014100

Fax +33233014130

Laboratoire de Radioécologie de Cherbourg-Octeville

Rue Max-Pol Fouchet

50130 Cherbourg-Octeville, France

\section{ABSTRACT:}

In the event of accidental discharges of radionuclides in particulate form by a nuclear plant, dry deposition is the only transfer pathway under dry atmospheric conditions. In this case, for the urban environment, these deposits must be assessed precisely in the urban canopy to estimate the doses potentially received by the population. The objectives of this wind tunnel study are to measure dry deposition velocities of a submicron fluorescein aerosol onto horizontal and vertical urban surfaces of glass, cement facing and grass for several wind speeds and to measure the turbulence parameters associated with these deposition velocities. These deposition velocities are then compared to data of the literature and to the 
results of two models for dry deposition. The dry deposition velocity of the fluorescein aerosol increases with the intensity of the turbulence. This highlights the importance of the turbulent processes of impaction and interception in deposition. However, the ratio of dry deposition velocity to friction velocity depends on the surface type. It depends on the turbulence conditions in the boundary layer. These turbulent dry deposition processes thus vary in importance depending on the studied surface. Finally, settling represents a significant part of the deposition for low wind speeds and for smooth surfaces. This wind tunnel study permits the study of the deposition as a function of turbulent processes. It should be supplemented by in situ experiments to take into account all the physical processes involved under real conditions.

41

42 KEYWORDS: Dry Deposition, Deposition Velocity, Submicron Aerosol, Urban Surfaces, Wind Tunnel. 


\section{Introduction}

In a polluted atmosphere or during transit of a plume containing stable or radioactive pollutants, and in the absence of rainfall events, dry deposition is the only transfer pathway from the air to the surface for particles and pollutants. At present, this dry deposition has been studied especially on natural surfaces representing the first link in the human food chain, but very little in the urban environment (Kelly, 1987; Fowler et al., 2009). However, a significant portion of the human population is concentrated in the urban environment, and in the case of passage of a radioactive plume, the quantity of radionuclides deposited by aerosols must be taken into account in estimating the dose rates received by the population (Kelly, 1987). Precise assessment of the transfer of pollutants by dry deposition of aerosols can thus be very important, and the lack of significant data for the urban environment is now acknowledged. Dry deposition of aerosols depends on the aerosol diameter, the deposition surface (the roughness and temperature, for example) and the turbulence conditions (Sehmel, 1980). Therefore aerosols do not deposit homogeneously in the urban environment. In the case of radioactive pollutants, this deposition must be studied for various surfaces, on a wall or street level, and not for an urban canopy, on a neighbourhood or city level, because the distribution of the deposits must be known precisely to assess the doses received by the residents. The dry deposition velocity is the coefficient used to quantify the transfer of aerosol particles by dry deposition in the environment. Most of the measurements of dry deposition velocities on urban surfaces in urban environments were conducted by Roed $(1983,1985,1987)$ as a result of the fallout from nuclear tests and the Chernobyl accident, and by Pesava et al. (1999) and Maro et al. (2010) with a tracer aerosol generated in situ. However, these deposition velocities are not associated with precise measurements of turbulence or local meteorology. Presently, there are very few experimental data related to turbulent parameters for urban environments and surfaces. As a result there are significant uncertainties in the use of predictive models of deposition for this environment (Fowler et al., 2009). Urban environments are complex and heterogeneous from the point of view of the turbulence and measurements under simple conditions should aid in understanding the deposition processes and quantifying deposition velocities on urban surfaces. The wind tunnel is an advantageous tool. It can be used as an initial approach to quantifying dry deposition velocities as a function of a restricted number of controlled parameters and reproducible experiments can be conducted. Dry deposition has already been the subject of wind tunnel studies, on natural surfaces (Chamberlain, 1967) or on smooth and rough substrates (Liu and Agarwal, 1974; Horvath et al., 1996; Toprak et al., 1997; Dai et al., 2001), but rather for micron particles. However, the accumulation mode of the atmospheric aerosol $\left(0.1 \mu \mathrm{m} \leq \mathrm{d}_{\mathrm{p}} \leq 1 \mu \mathrm{m}\right)$ is 
the mode that is the primary vector for chemical pollutants and radionuclides. It is the mode on which the surface distribution of the atmospheric aerosol is centred (Gründel and Porstendörfer, 2004; Van Dingenen et al., 2004; Papastefanou, 2008). Moreover, it transports these pollutants over large distances from a source to the urban environments, due to a relatively long residence time in the atmosphere (Jaenicke, 1988; Papastefanou, 2006). While the deposition of particles greater than a micrometre most often studied is strongly affected by sedimentation, deposition of submicron aerosols, which are less studied, results from the contribution of several physical processes (Brownian diffusion, impaction, interception). The main objective of this study is to quantify dry deposition velocities of a submicron aerosol on horizontal and vertical urban surfaces, for several wind speeds and under isothermal conditions in the wind tunnel. Various turbulent boundary layer conditions are thus encountered. These turbulence conditions associated with the dry deposition velocities are quantified by hot wire anemometer measurements and focus especially on determination of the friction velocities. Finally, the data from this study are compared to data in the literature and to operational models, solved analytically, developed for smooth surfaces (Lai and Nazaroff, 2000) and natural canopies (Zhang et al., 2001).

\section{Experimental setup}

\section{II.1 The wind tunnel and the studied surfaces}

The experiments were conducted in a recirculating wind tunnel of the IRPHE (University of Aix-Marseille, campus of Luminy, Marseille, France). The experimental test section is a glass channel with a stainless steel base $8650 \mathrm{~mm}$ long and a cross-section $280 \mathrm{~mm}$ high and $640 \mathrm{~mm}$ width. Airflow speeds between 0.5 and $19 \mathrm{~m} \mathrm{~s}^{-1}$ can be generated. Deposition was studied on horizontal conventional glass surfaces, cement facing and synthetic grass in a first experimental campaign (Fig. 1.a), then on vertical conventional glass and cement facing surfaces in a second campaign (Fig. 1.b). The commercial names of the materials and the roughness parameters of the cement facing (Flori et al., 2007) and synthetic grass are listed in Table 1. The roughness parameters of the cement facing measured by laser roughness measurements are the arithmetic mean deviation of the profile Ra, the standard deviation of the profile Rq, the valley depth of the profile Rv and the peak height of the profile Rp. The synthetic grass is composed of primary straight blades grouped into tufts, and thinner and shorter curly blades included in the canopy to make it denser. The parameters characterising the synthetic grass were determined by the authors for the primary straight blades and are the average canopy height $h_{c}$, the length of the straight blades $l_{b}$, the width of these blades $\mathrm{w}_{\mathrm{b}}$, the number of tufts per square metre $\mathrm{n}_{\mathrm{t}}$ and the number of straight blades per 


\begin{tabular}{llll}
\hline & Conventional glass & Cement facing & Synthetic grass \\
\hline Commercial name & Planilux $\Theta$, Saint-Gobain & Fema®-Therm-Mineralputz $5 \mathrm{~mm}$ & "Romana" \\
Roughness parameters & Glass thickness $=4 \mathrm{~mm}$ & $\mathrm{Ra}=0.57 \mathrm{~mm}$ & $\mathrm{~h}_{\mathrm{c}}=34 \pm 2 \mathrm{~mm}$ \\
& & $\mathrm{Rq}=0.74 \mathrm{~mm}$ & $\mathrm{l}_{\mathrm{b}}=38.4 \pm 1.9 \mathrm{~mm}$ \\
& $\mathrm{Rv}=2.36 \mathrm{~mm}$ & $\mathrm{w}_{\mathrm{b}}=1.2 \pm 0.1 \mathrm{~mm}$ \\
& $\mathrm{Rp}=1.86 \mathrm{~mm}$ & $\mathrm{n}_{\mathrm{t}}=10364 \mathrm{~m}^{-2}$ \\
& & $\mathrm{n}_{\mathrm{b}}=164675 \mathrm{~m}^{-2}$ \\
\hline
\end{tabular}

square metre $n_{b}$. During the experiments on horizontal surfaces, the bottom of the test section was successively completely covered by each type of surface to develop the boundary layers and turbulence conditions characteristic of each surface.

Table 1: characteristics of the studied surfaces.
109

In the same way, a vertical wall of the test section was successively covered with conventional glass and cement facing, to measure deposition on a vertical wall. It should be noted that glass cover the walls in the form of a pavement of square plates $200 \mathrm{~mm}$ on a side, while the cement facing and synthetic grass covered the wind tunnel homogeneously and continuously. To study deposition over a broad range of wind speeds that can be encountered in the urban environments, airflows of speeds $u_{\text {ref }}$ of $1.3,5.0$ and $9.9 \mathrm{~m} \mathrm{~s}^{-1}$ were generated in the test section. The turbulence was quantified above all the horizontal surfaces.

\section{II.2 Quantification of the dry deposition velocity $\mathrm{V}_{\mathrm{d}}$}

The dry deposition velocity $V_{d}\left(\mathrm{~m} \mathrm{~s}^{-1}\right)$ of an aerosol is defined by Chamberlain and Chadwick (1953, in Sehmel, 1980) as the ratio of the surface flux of dry deposition $\mathrm{F}\left(\mathrm{kg} \mathrm{m}^{-2} \mathrm{~s}^{-1}\right.$; by convention a deposition flux is negative) by the average concentration of the aerosol in the air $\mathrm{C}\left(\mathrm{kg} \mathrm{m}^{-3}\right)$ at a given height (1).

$$
\mathrm{V}_{\mathrm{d}}=\frac{-\mathrm{F}}{\mathrm{C}}
$$

A common approach to measure dry deposition velocities is to use a stable or radioactive chemical tracer for the studied aerosol. This method has the advantage of directly measuring a quantity of tracer, and thus of particles, in number or in mass. The deposition flux $F$ is calculated according to (2), $M_{\text {substrate }}(\mathrm{kg})$ is the mass of tracer, $A_{\text {substrate }}\left(\mathrm{m}^{2}\right)$ is the total surface of the substrate sample, and $t(s)$ is the duration of the experiment. 


$$
-F=\frac{M_{\text {substrate }}}{A_{\text {substrate }} t}
$$

The average concentration $\mathrm{C}$ is calculated according to (3), with $\mathrm{M}_{\text {filter }}(\mathrm{kg})$ the mass of tracer collected on the filter with an airflow rate $\mathrm{Q}_{\text {filter }}\left(\mathrm{m}^{3} \mathrm{~s}^{-1}\right)$ over the same duration $\mathrm{t}$.

$$
\mathrm{C}=\frac{\mathrm{M}_{\text {filter }}}{\mathrm{Q}_{\text {filter }} \mathrm{t}}
$$

A slightly polydispersed monomodal submicron dry fluorescein aerosol (uranine, $\rho=1500 \mathrm{~kg} \mathrm{~m}^{-3}$ ) generated with a pneumatic generator is used as a tracer. The operating principle of this generator is described in French standard NF X 44-011. A fluorescein solution is nebulised, the produced droplets are sorted by centripetal filters, then entrained and dried by a dry air flow to obtain a dry solid fluorescein aerosol. The granulometric mass distribution of this aerosol was measured by three samplings with a Dekati (LPI) low pressure cascade impactor (separation of the particles over 12 stages of cutoff diameters between $24 \mathrm{~nm}$ and $9.55 \mu \mathrm{m}$ ) and gave on average an aerodynamic mass median diameter $d_{\mathrm{amm}}$ of $0.27 \pm 0.07 \mu \mathrm{m}$ with a geometric standard deviation of $2.06 \pm 0.23$ (Fig. 2). The air recirculation in the wind tunnel allows to generate particles only for the first two minutes of the experiment and to let the concentration to decrease with time until the end of the experiment. Substrate samples are removed at the end of the fifteen minutes of the experiment. The generated aerosol is introduced at the outlet of the test section to be mixed with air in the recirculation section of the wind tunnel so that its concentration will be homogeneous over the test section inlet. It is injected at the centre of the cross-section with a horizontal copper injection nozzle regularly pierced along a line oriented toward the outlet duct with an airflow rate of $10.8 \mathrm{~m}^{3} \mathrm{~h}^{-1}$. Finally, the air in the test section is renewed between experiments by extracting air towards the exterior. The dry deposition fluxes are measured by exposure of samples (square plates $200 \mathrm{~mm}$ on a side composed of the studied substrates) to the fluorescein aerosols for a the experiment time. Samples are used for several experiments. After they are rinsed with distilled water and dried at room temperature, the substrates are placed in the test section with great care so as not to pollute them with fluorescein deposited on the walls of the test section. The static electrical charge is consistently removed from the synthetic grass samples by spraying the blades with denatured ethanol. The charge state of these specimens is then checked with a fieldmeter (Eltex EMF 58). During the experiments on horizontal substrates, three rows of three samples placed across the width of the test section are incorporated into the substrate studied at various distances from the test section inlet. These distances from the inlet are also called "fetch" $(\mathrm{m})$. The edges of these specimens adjoin the substrate surfaces covering the base of the test section. The leading edges of each row of samples are located at 
1.0, 5.0 and $6.8 \mathrm{~m}$ from the inlet. Each type of substrate is studied separately, as the base of the section is completely covered by a single type of substrate. To measure dry deposition velocities on vertical surfaces, the vertical wall used is covered in the same way with the studied substrate, from the test section inlet to $6 \mathrm{~m}$ inside the test section. Three samples are intercalated lengthwise into this vertical wall, with leading edges at $4.8,5.0$ and $5.2 \mathrm{~m}$, to measure the dry deposition fluxes. These specimens are centred in height, $40 \mathrm{~mm}$ from the base of the test section. In parallel, samples are taken on cellulose filters (Whatman 1440-047) throughout the exposure time of the specimens to the aerosol in order to quantify its concentration in the air of the test section. Bent copper sampling tubes with a $10 \mathrm{~mm}$ inside diameter are introduced from the top of the section so as not to perturb the flow above the studied surfaces and connected to filter holders with $500 \mathrm{~mm}$ long fluoroelastomer tubing. During the experiments on horizontal substrates, three samples are taken on filters $10 \mathrm{~mm}$ above the surface halfway across the test section, downstream of the specimens, with the inlet of the tube just behind each row of samples (fetch $=1.2,5.2$ and $7.0 \mathrm{~m}$ ) so as not to perturb the flow over the specimens and thus not to perturb deposition. Likewise, for the experiments on vertical substrates, a sample is taken on a filter just behind the third specimen, $10 \mathrm{~mm}$ from the wall, halfway up the test section. In each experiment, a sample is taken on a filter at the centre of the test section, $5.2 \mathrm{~m}$ from its entrance, to control a posteriori the homogeneity of the particle concentration in the air in the section during the experiment. Collection flow rates are between 7.6 and $8.6 \mathrm{~L} \mathrm{~min}^{-1}$ and are checked with a TSI 4000 Series mass flowmeter. The samples and filters are carefully removed, wrapped in aluminium foil to avoid any pollution, and then treated for measurement. Fluorescein is hydrophilic, thus the deposited particles are dissolved simply by rinsing the surface with a $\mathrm{pH} 9$ solution of ammonia water using a syringe (with successive rinsings with the same solution for the glass and cement facing) or directly by soaking (synthetic grass). The filters are immersed directly in the ammonia water to dissolve the filtered fluorescein particles. These solutions are measured with a fluorescence spectrometer (Jobin Yvon Horiba FluoroMax-3) to determine $\mathrm{M}_{\text {substrate }}$ and $\mathrm{M}_{\text {fitter }}$. The background fluorescence of each type of surface is subtracted from the measurement result. Experiments are conducted at least twice to ensure their repeatability.

\section{II.3 Estimation of the turbulent parameters}

In the wind tunnel, in the absence of heat exchange on the studied surface, the turbulent parameter mainly associated with $V_{d}$ is the friction velocity $u_{*}\left(\mathrm{~m} \mathrm{~s}^{-1}\right)$ because it quantify mechanical turbulence that enhance the aerosol deposition. Also, it is one of the parameters necessary in modelling $V_{d}$ in confined environments (Lai and Nazaroff, 2000) or in situ (Zhang et al., 2001). It quantifies the turbulence 
generated by shear of a flow over a surface and is used as a reference velocity near the wall. The friction velocity is estimated with (4) by measuring $\tau_{\mathrm{p}}\left(\mathrm{kg} \mathrm{m}^{-1} \mathrm{~s}^{-2}\right)$, the frictional or shear stress at the wall, with $\rho$ $\left(\mathrm{kg} \mathrm{m}^{-3}\right)$ the fluid density.

$$
\mathrm{u}_{*}=\sqrt{\frac{\tau_{\mathrm{p}}}{\rho}}
$$

It can also be estimated with (5) using velocity profile measurements above the surface.

$$
\begin{gathered}
\frac{\mathrm{u}(\mathrm{z})}{\mathrm{u}_{*}}=\frac{1}{\kappa} \ln \frac{\mathrm{z}-\mathrm{d}}{\mathrm{z}_{0}} \\
\frac{\mathrm{u}(\mathrm{z})}{\mathrm{u}_{*}}=\frac{1}{\kappa} \ln \frac{\mathrm{z}-\mathrm{d}}{\mathrm{k}_{\mathrm{s}}}+\mathrm{B}
\end{gathered}
$$

In (5), $\mathrm{u}(\mathrm{z})\left(\mathrm{m} \mathrm{s}^{-1}\right)$ is the mean velocity in the flow direction measured at the vertical position $\mathrm{z}(\mathrm{m})$, and $\kappa(0.4), d(m)$ and $z_{0}(m)$ are respectively the Von Karman constant, the displacement height and the aerodynamic roughness height. The friction velocity can be estimated by fitting this relation in the logarithmic overlap area of the velocity profile of a developed turbulent boundary layer; $\mathrm{u}_{*}, \mathrm{~d}$ and $\mathrm{z}_{0}$ are then the parameters to be fitted. The aerodynamic roughness height is flow-dependent for dynamically smooth flows and depends on roughness geometry for fully rough flows (Raupach et al., 1991). For synthetic grass, $z_{0}$ is equal to $0.13 h_{c}$ (Tanner and Pelton, 1960, Stanhill, 1969 in Raupach et al., 1991). For cement facing, $\mathrm{z}_{0}$, is determined from (5) and (6), and equal to $\mathrm{k}_{\mathrm{s}} \exp (-\mathrm{B} \kappa)(\mathrm{B}=8.5$; Schlichting, 1968), with $k_{s}=R v+R p$. For glass, $d$ is equal to zero and $z_{0}$ can vary. The relative turbulence intensity $I(\%)$ is another dimensionless magnitude that quantifies the turbulent agitation $\left(u^{\prime}, w^{\prime}\right)$ of a flow by comparison to the average motion $(\overline{\mathrm{u}})$ at a distance $\mathrm{z}$ from the wall. The relative turbulence intensities for the components $u$ and $w\left(I_{u}\right.$ and $\left.I_{w}\right)$ can be calculated according to (7.a) and (7.b).

$$
I_{u}=\frac{\sqrt{\overline{u^{\prime 2}}}}{\bar{u}} ; I_{w}=\frac{\sqrt{\overline{w^{\prime 2}}}}{\bar{u}}
$$

With this magnitude, turbulence can be classified into three categories: low (1\%), medium (10\%) and high (20\% and more). The turbulent parameters were estimated in absence of aerosol injection for horizontal surfaces using hot-wire anemometry operating at high frequency. The system used is a probe with two crossed hot wires (type 55P61) combined with a Streamline anemometry system (Dantec Dynamics). It measures $\mathrm{u}$, the horizontal component of velocity in the flow direction, and $\mathrm{w}$, the vertical component, at high frequencies $\left(2.5 \mathrm{kHz}\right.$ for $\mathrm{u}_{\mathrm{ref}}=1.3 \mathrm{~m} \mathrm{~s}^{-1}$ and $10 \mathrm{kHz}$ for $\mathrm{u}_{\mathrm{ref}}=5.0$ and $9.9 \mathrm{~m} \mathrm{~s}^{-1}, \mathrm{u}_{\mathrm{ref}}$ measured at the center of the test section of the wind tunnel) with a 50 seconds acquisition duration in each position. 
These turbulence measurements were conducted above each surface type for each $\mathrm{u}_{\mathrm{ref}}$ and for each fetch above the centre of the central substrate sample, by vertical profiles of 40 points between $\mathrm{z}=2.5 \mathrm{~mm}$ and $\mathrm{z}=200 \mathrm{~mm}$ above the roughnesses of the surfaces.

\section{III. Results and discussions}

212

213

\section{III.1 Dry deposition velocities $V_{d}$}

The measured concentrations of aerosols in the air show no significant difference between the sample in the centre of the test section and samples $10 \mathrm{~mm}$ from the walls during the experiments (median deviation of $6.6 \%$ ) and show homogenisation of the aerosol concentration in the air recirculation circuit of the wind tunnel. The average dry deposition velocities on each type of horizontal surface are calculated from the deposition fluxes at 1.0, 5.0 and $6.8 \mathrm{~m}$ from the test section inlet and the associated concentrations for each flow speed. They show neither variation with the fetch, nor a notable difference between the specimens at the centre of the row and those on the sides. The average dry deposition velocities calculated for each type of surface, horizontal and vertical, and for each airflow speed $u_{\text {ref }}$ are shown in Table 2 and Fig. 3. The dry deposition velocities measured on horizontal surfaces vary from $1.210^{-5} \mathrm{~m} \mathrm{~s}^{-1}$ on conventional glass for $u_{\mathrm{ref}}=1.3 \mathrm{~m} \mathrm{~s}^{-1}$, to $1.410^{-3} \mathrm{~m} \mathrm{~s}^{-1}$ on synthetic grass for $u_{\mathrm{ref}}=9.9 \mathrm{~m} \mathrm{~s}^{-1}$. Thus there is a factor of over two orders of magnitude between the lowest and highest values measured on these urban surfaces.

Table 2: average $\mathrm{V}_{\mathrm{d}}$ as a function of $\mathrm{u}_{\mathrm{ref}}$.

\begin{tabular}{|c|c|c|c|c|c|}
\hline \multirow{3}{*}{$\mathbf{u}_{\text {ref }}\left(\mathrm{m} \mathrm{s}^{-1}\right)$} & \multicolumn{5}{|c|}{$V_{d}\left(x 10^{-5} \mathrm{~m} \mathrm{~s}^{-1}\right)$} \\
\hline & \multicolumn{2}{|c|}{ Glass } & \multicolumn{2}{|c|}{ Cement facing } & \multirow[t]{2}{*}{ Synthetic grass } \\
\hline & Horizontal & Vertical & Horizontal & Vertical & \\
\hline 1.3 & $1.4 \pm 0.4$ & & $2.2 \pm 0.9$ & $1.4 \pm 0.3$ & $28.1 \pm 8.4$ \\
\hline 5.0 & $2.3 \pm 1.3$ & $1.1 \pm 0.4$ & $4.8 \pm 1.8$ & $3.6 \pm 0.7$ & $54.6 \pm 19.3$ \\
\hline 9.9 & $4.5 \pm 2.0$ & $2.4 \pm 0.3$ & $7.2 \pm 1.6$ & $8.0 \pm 2.0$ & $124.7 \pm 29.6$ \\
\hline
\end{tabular}

Those measured on vertical surfaces vary from $1.110^{-5} \mathrm{~m} \mathrm{~s}^{-1}$ on conventional glass for $u_{\text {ref }}=5.0 \mathrm{~m} \mathrm{~s}^{-1}$ to $8.010^{-5} \mathrm{~m} \mathrm{~s}^{-1}$ on cement facing for $\mathrm{u}_{\mathrm{ref}}=9.9 \mathrm{~m} \mathrm{~s}^{-1}$. The dry deposition velocity $\mathrm{V}_{\mathrm{d}}$ could not be measured on vertical conventional glass for $\mathrm{u}_{\mathrm{ref}}=1.3 \mathrm{~m} \mathrm{~s}^{-1}$ during the experimental campaign. 


\section{III.2 Turbulent parameters}

231

232

233

234

235

236

237

238

239

240

241

242

243

244

245

246

247

248

249

250

251

252

253

254

255

256

257

258

Aerodynamic parameters determined by hot wire measurements are listed in Table 3 . All the developed boundary layers are turbulent at fetches of $1.1,5.1$ and $6.9 \mathrm{~m}$, with a transition zone to the logarithmic profile (Fig. 4). The friction velocities are determined by fitting the logarithmic relation (5) to the mean velocity profiles. The estimated friction velocities decrease for an increasing fetch. This variation is consistent with the reduction in the stress at the wall $\tau_{\mathrm{p}}$ upon development of a completely turbulent boundary layer (Antonia and Luxton, 1971). The representation of the profiles in terms of dimensionless velocity $(\mathrm{u}+\Delta u)+$ and dimensionless vertical position $(\mathrm{z}+\mathrm{d})+\left(\mathrm{u}+=\mathrm{u} / \mathrm{u}_{*} ; \mathrm{z+}=\mathrm{zu} / \mathrm{v}\right.$, with $v$ the kinematic viscosity of air) and the mean velocity shifts values $\Delta u$, with $\Delta u=\operatorname{lnz}_{0}++C(C=5)$, show the different rough regimes of the flows generated by each surface type at each $\mathrm{u}_{\mathrm{ref}}$ (Krogstad and Antonia, 1999).

The profiles of $I_{u}$ and $I_{w}$ were calculated using (7.a) and (7.b), and profiles of $I_{w}$ are shown in Fig. 5. All the profiles over $u$ and $w$ have the same shape, with a maximum $I_{\mathrm{wmax}}$ in the immediate vicinity of the surface. The calculated values are shown in Table 3. For equal $u_{r e f}$, the values of $I_{u m a x}$ and $I_{w m a x}$ are higher for synthetic grass than for cement facing, and higher for cement facing than for glass, with $\mathrm{I}_{\text {umax }}$ greater than $I_{\text {wmax }}$. These observations are consistent with the observations of Antonia and Luxton (1971) for a boundary layer on a rough surface. Unlike the friction velocities, these relative turbulence intensities show no notable decrease as a function of the fetch but are essentially constant at each fetch for the same surface at the same flow speed.

\section{III.3 Discussions}

The average deposition velocities for each type of surface and each $\mathrm{u}_{\mathrm{ref}}$ (Table 2) have been compared to the data of the literature (Fig. 6). The deposition velocities measured in this study are of the same order of magnitude as those in the literature for smooth surfaces and grass. The absence of data on the geometry of the surface roughnesses studied by Toprak et al. (1997) makes it impossible to understand the differences in the measured $V_{d}$. The dry deposition velocities vary with the mean air flow speed, the surface type and the orientation of the surface. On horizontal surfaces, $V_{d}$ varies on average by a factor of 1.7 and 23.7 respectively between conventional glass and cement facing and between conventional glass and synthetic grass, and by a factor of 1.9 and 3.6 between $u_{\text {ref }}=1.3 \mathrm{~m} \mathrm{~s}^{-1}$ and $u_{\text {ref }}=5.0 \mathrm{~m} \mathrm{~s}^{-1}$ and between $\mathrm{u}_{\mathrm{ref}}=1.3 \mathrm{~m} \mathrm{~s}^{-1}$ and $\mathrm{u}_{\mathrm{ref}}=9.9 \mathrm{~m} \mathrm{~s}^{-1}$ respectively. 


\begin{tabular}{|c|c|c|c|c|c|c|c|c|c|c|c|c|c|c|c|c|c|c|}
\hline \multirow[b]{2}{*}{$\begin{array}{l}\text { Fetch } \\
\text { (m) }\end{array}$} & \multirow[b]{2}{*}{$\begin{array}{c}\mathbf{u}_{\mathrm{ref}} \\
\left(\mathrm{m} \mathrm{s}^{-1}\right)\end{array}$} & \multicolumn{5}{|c|}{ Conventional glass } & \multicolumn{6}{|c|}{ Cement facing } & \multicolumn{6}{|c|}{ Synthetic grass } \\
\hline & & $\begin{array}{c}\mathrm{V}_{\mathrm{d}} \\
\left(10^{-4}\right. \\
\left.\mathrm{m} \mathrm{s}^{-1}\right)\end{array}$ & $\begin{array}{c}\mathbf{u}^{*} \\
\left(\mathrm{~m} \mathrm{~s}^{-1}\right)\end{array}$ & $\begin{array}{c}z_{0} \\
\left(10^{-2}\right. \\
\mathrm{mm})\end{array}$ & $\begin{array}{l}\mathbf{I}_{\max } \\
(\%)\end{array}$ & $\begin{array}{l}\mathbf{I}_{\text {wax }} \\
(\%)\end{array}$ & $\begin{array}{c}\mathrm{V}_{\mathrm{d}} \\
\left(10^{-4}\right. \\
\left.\mathrm{m} \mathrm{s}^{-1}\right)\end{array}$ & $\begin{array}{c}\mathbf{u}^{*} \\
\left(\mathrm{~m} \mathrm{~s}^{-1}\right)\end{array}$ & $\begin{array}{c}z_{0} \\
\left(10^{-2}\right. \\
\mathrm{mm})\end{array}$ & $\begin{array}{c}\text { d } \\
(\mathrm{mm})\end{array}$ & $\begin{array}{l}I_{\text {max }} \\
(\%)\end{array}$ & $\begin{array}{l}I_{\text {max }} \\
(\%)\end{array}$ & $\begin{array}{c}\mathrm{V}_{\mathrm{d}} \\
\left(10^{-4}\right. \\
\left.\mathrm{m} \mathrm{s}^{-1}\right)\end{array}$ & $\begin{array}{c}\mathbf{u}_{*} \\
\left(\mathrm{~m} \mathrm{~s}^{-1}\right)\end{array}$ & $\begin{array}{c}\mathrm{z}_{0} \\
(\mathrm{~mm})\end{array}$ & $\begin{array}{c}\text { d } \\
(\mathrm{mm})\end{array}$ & $\begin{array}{l}\mathbf{I}_{\max } \\
(\%)\end{array}$ & $\begin{array}{r}\mathbf{I}_{\text {wmax }} \\
(\%)\end{array}$ \\
\hline 1.1 & & 1.7 & & & & & 3.1 & & & & & & 3.3 & 0.17 & 4.4 & 23.9 & 38.3 & 18.7 \\
\hline 5.1 & 1.3 & 1.2 & 0.06 & 8.5 & 25.4 & 7.2 & 1.9 & 0.07 & 0.1 & 5.6 & 25.8 & 7.4 & 2.6 & 0.13 & 4.4 & 20.9 & 33.5 & 14.9 \\
\hline 6.9 & & 1.1 & 0.06 & 8.7 & 24.7 & 7.5 & 1.8 & 0.07 & 0.1 & 4.5 & 26.8 & 7.0 & 2.6 & 0.13 & 4.4 & 16.1 & 35.3 & 16.6 \\
\hline 1.1 & & 2.8 & 0.26 & 9.9 & 23.6 & 10.1 & 4.9 & 0.33 & 0.1 & 6.4 & 21.2 & 11.0 & 7.0 & 0.67 & 4.4 & 24.0 & 44.7 & 23.7 \\
\hline 5.1 & 5.0 & 1.4 & 0.23 & 4.2 & 21.2 & 8.7 & 4.3 & 0.29 & 0.1 & 4.0 & 24.3 & 10.1 & 5.8 & 0.52 & 4.4 & 17.6 & 47.6 & 24.9 \\
\hline 6.9 & & 2.2 & 0.20 & 1.9 & 21.2 & 8.1 & 5.2 & 0.27 & 0.1 & 2.5 & 24.0 & 10.2 & 3.9 & 0.56 & 4.4 & 13.1 & 42.5 & 23.4 \\
\hline 1.1 & & 5.6 & 0.50 & 5.9 & 19.1 & 9.3 & 7.6 & 0.66 & 0.1 & 5.1 & 22.8 & 11.7 & 13.1 & 1.37 & 4.4 & 24.0 & 46.6 & 26.0 \\
\hline 5.1 & 9.9 & 2.9 & 0.46 & 3.1 & 18.7 & 8.6 & 6.5 & 0.54 & 0.1 & 4.0 & 23.5 & 10.5 & 12.1 & 1.06 & 4.4 & 15.6 & 44.7 & 25.6 \\
\hline 6.9 & & 6.3 & 0.38 & 1.5 & 16.9 & 8.9 & 7.4 & 0.54 & 0.1 & 2.8 & 25.4 & 11.2 & 12.1 & 1.05 & 4.4 & 9.0 & 44.6 & 24.8 \\
\hline
\end{tabular}


263 These results show the importance of turbulent processes of interception and impaction for this size range of particles, dependent respectively on the sizes of the aerosol and the obstacle, and on the Stokes number (itself dependent on the relaxation time of the aerosol, the flow speed and the size of the obstacle). Moreover, the measured differences in deposition velocities between horizontal and vertical walls, conventional glass and cement facing are on the order of the sedimentation velocity for the fluorescein aerosol calculated with (7) from the distribution of Fig 2.

$$
\mathrm{V}_{\mathrm{s}}=\sum_{\mathrm{i}=1}^{12} \frac{\mathrm{d}_{\mathrm{pi}}^{2} \mathrm{gC}_{\mathrm{ui}} \rho}{18 v} \mathrm{~m}_{\mathrm{ni}}=1.10 \pm 0.3710^{-5} \mathrm{~m} \mathrm{~s}^{-1}
$$

269

Here, $\mathrm{g}$ is the gravitational acceleration $\left(9.81 \mathrm{~m} \mathrm{~s}^{-2}\right), \rho$ is the density of the particles $\left(1000 \mathrm{~kg} \mathrm{~m}^{-3} \mathrm{for}\right.$ aerodynamic diameters determined with a cascade impactor,) $\mathrm{C}_{\mathrm{ui}}$ is the Cunningham correctional factor for the aerosol of diameter $\mathrm{d}_{\mathrm{pi}}$ (geometric diameter of stage $\mathrm{i}$ of the cascade impactor), $v$ is the kinematic viscosity of air $\left(1.510^{-5} \mathrm{~m}^{2} \mathrm{~s}^{-1}\right)$ and $\mathrm{m}_{\mathrm{ni}}$ is the fluorescein mass on stage i normalised to the total mass of fluorescein collected on the 12 stages. For low wind speeds, the contribution of sedimentation to deposition of this fluorescein aerosol is therefore non-negligible, contrary to what is usually believed for submicron aerosols. It can double the deposition velocity between a vertical wall and a horizontal wall, or even represent the entire deposit on a smooth horizontal wall for a low wind speed, as for glass with $u_{r e f}=1.3 \mathrm{~m} \mathrm{~s}^{-1}$. It should also be noted that deposition velocities on horizontal and vertical cement facing are approximately equal at $u_{r e f}=9.9 \mathrm{~m} \mathrm{~s}^{-1}$. As the deposition flux depends on the vertical wind speed and its fluctuations, the deposition velocity $V_{d}$ is shown in Fig. 7 as a function of the maximum relative turbulence intensity over w, $\mathrm{I}_{\mathrm{wmax}}$. An increase in deposition flux with turbulence intensity was already observed by Dai et al. (2001) for a smooth surface. Our graph shows a variation in $V_{d}$ as a function of $I_{w m a x}$ independent of a particular type of surface. This observation is of interest as it represents $V_{d}$ as a function of a single turbulent parameter for several surface types.

The parameter usually related to $V_{d}$ is the friction velocity $u_{*}$, as it quantifies the turbulence in a boundary layer. It is one of the main parameters used in the deposition models developed for inside and outside environments. The calculated deposition velocities for the polydispersed fluorescein aerosol with the models of Lai and Nazaroff (2000) and of Zhang et al. (2001) (with zero aerodynamic resistance, because the concentration above the surface is consistent with that measured in the centre of the test section), and the data of this study are shown as a function of $\mathrm{u}_{*}$ in Fig. 8. The friction velocities of the vertical surfaces associated with the $V_{d}$ are those estimated for the same horizontal surfaces and same $u_{r e f}$ at the 
fetch $5.0 \mathrm{~m}$. The model of Lai and Nazaroff (2000) correctly estimates the deposition velocities on glass for $\mathrm{u}_{*}$ greater than $0.2 \mathrm{~m} \mathrm{~s}^{-1}$, but seems to overestimate them below this for horizontal glass.

On the other hand, Zhang et al. (2001) systematically overestimate $V_{d}$ on grass by more than a factor of 5. This resistive model uses Brownian diffusion as the principal deposition process for a submicron aerosol deposition on grass and underestimates interception and impaction processes. By comparison, the recent mechanistic model of Petroff et al. (2008) accords more importance to interception for this aerosol size range. It is in a better agreement with Chamberlain (1967) data on grass in a wind tunnel for micron and submicron aerosols than Zhang et al. (2001). This shows the limits of the operational model of Zhang et al. (2001) in assessing $\mathrm{V}_{\mathrm{d}}$ on grass precisely, and the need to either improve consideration of turbulent processes in deposition on grass, or to estimate $V_{d}$ from mechanistic models like that of Petroff et al. (2008) that better account for these turbulent processes.

In the literature, dry deposition velocities measured in situ are generally normalised to $\mathrm{u}_{*}$. In this case, the sedimentation velocity $V_{s}(7)$, a non-turbulent deposition process, must be subtracted from $V_{d}$. In recent studies of transfers in natural environments, the ratio of $V_{d}$ and $u_{*}$ was found to be independent of the various surfaces studied under neutral and stable conditions and approximately equal to $2.10^{-3}$ (Damay, 2010; Donateo et al., 2010). On the contrary, in this study, this ratio depends on the type of surface (Fig. 9) and thus on the flow conditions and the structure of the boundary layer. It is therefore determined by the importance of interception and impaction in the deposition process. The ratio is $5.3 \pm 4.110^{-5}$ for conventional glass, $1.5 \pm 0.610^{-4}$ for cement facing, and $1.3 \pm 0.310^{-3}$ for synthetic grass. The experimental results are close to the estimate of the model of Lai and Nazaroff (2000) for glass $\left(5.0 \pm 0.110^{-5}\right)$ and the in situ values of Damay (2010) on a grassland, $0.810^{-3}$ and $1.610^{-3}$ respectively for $\mathrm{d}_{\mathrm{p}}=0.20$ and $0.32 \mu \mathrm{m}$, for synthetic grass.

In the urban canopy, in the urban sub-layer of the atmospheric boundary layer, measurable friction velocity $u_{*}$ in the boundary layers of the surfaces is not obvious. Use of $u_{*}$ alone as a turbulent parameter seems thus to be limited in modelling deposition on heterogeneous urban surfaces. As an initial approach, in the context of operational models to give quick estimates of deposition velocities, wind speed in the streets could turn out to be a good parameter, as it is easily measurable or modelled. Empirical parameterisation of $\mathrm{V}_{\mathrm{d}}$ as a linear function of $\mathrm{u}_{\mathrm{ref}}$ for each type of surface according to the data of Table 2 could be a good first approximation. 


\section{IV. Conclusions}

321 Presently, there is little experimental data on dry deposition velocities for the urban environment. This

322

323

324

325

326

327

328

329

330

331

332

333

334

335

336

337

338

339

340

\section{V. REFERENCES}

Antonia R. A., Luxton R. E., 1971. The response of a turbulent boundary layer to a step change in surface

wind tunnel study was conducted to measure $V_{d}$ and the associated turbulent parameters for a polydispersed submicron aerosol on urban surfaces. The deposition velocity $\mathrm{V}_{\mathrm{d}}$ was measured on three urban surfaces types, horizontal and vertical, and for three flow speeds $u_{\text {ref, }}$ and these data were compared to the data of other authors. These deposition velocities show dependence on both $\mathrm{u}_{\mathrm{ref}}$ and the type of deposition surface, confirming the importance of the turbulent processes of interception and impaction in deposition for an aerosol of this size. However, sedimentation is responsible for a large part of the deposition for smooth horizontal surfaces and for low $\mathrm{u}_{\text {ref. }}$ The model of Lai and Nazaroff (2000) correctly estimates $V_{d}$ on glass, while Zhang et al. (2001) substantially overestimate it on grass. Finally, this work reveals that parameterisation of $\mathrm{V}_{\mathrm{d}}$ as a function of $\mathrm{u}_{\mathrm{ref}}$ may be relevant for the urban environment in an operational context.

This wind tunnel study treats only a limited number of parameters and types of surfaces. However, it highlights the absence of a single parameterisation for the deposition velocity as a function of aerodynamic parameters for smooth or rough surfaces. This absence is certainly due to the lack of reported data with turbulent parameters and the lack of deposition experiments on rough walls, even for simple roughness geometries. In the case of pollution by radionuclides, the disparity in the deposition velocities about two orders of magnitude measured in this study shows the importance of a local estimate of depositions in the urban canopy for each surface, rather than an estimate on the scale of entire neighbourhoods. Finally, a wind tunnel study can only constitute a first step in studying dry deposition in the urban environment and should be supplemented by in situ measurements. roughness, part 1. Smooth to rough. Journal of Fluid Mechanics 48, 721-761.

Chamberlain A.C., 1967. Transport of Lycopodium spores and other small particles to rough surfaces. Proceedings of the Royal Society London, 296 A.

Dai W., Davidson C.I., Etyemezian V., Zufall M., 2001. Wind tunnel studies of particles transport and deposition in turbulent boundary flows. Aerosol Science and Technology 35, 887-898. 
Damay P., 2010. Détermination expérimentale de la vitesse de dépôt sec des aérosols submicroniques en milieu naturel: influence de la granulométrie, des paramètres micrométéorologiques et du couvert. Thèse de doctorat de l'INSA de Rouen.

Donateo A., Damay P. E., Contini D., Maro D., Roupsard P., 2010. Similarities and differences in dry deposition velocity normalized to friction velocity over maize, grass, bare soil and ice measured with different instruments. International Aerosol Conference 2010, Helsinki.

Flori J.P., Giraud D., Olive F., Ruot B., Sini J.F, Rosant J.M., Mestayer P., Connan O., Maro D., Hébert D., Rozet M., Talbaut M., Coppalle A., 2007. Salissures de façades (SALIFA), Programme PRIMEQUAL, rapport final. EN-CAPE 07.129 C.

Fowler D., Pilegaard K., Sutton M.A., Ambus P., Raivonen M., Duyzer J., Simpson D., Fagerli H., Fuzzi S., Schjoerring J.K., Granier C., Neftel A., Isaksen I.S.A., Laj P., Maione M., Monks P.S., Bukhardt J., Daemmgen U., Neirynck J., Personne E., Wichink-Kruit R., Butterbach-Bahl K., Flechard C., Tuovinen J.P., Coyle M., Gerosa G., Loubet B., Altimir N., Gruenhage L., Ammann C., Cieslik S., Paoletti E., Mikkelsen T.N., Ro-Poulsen H., Cellier P., Cape J.N., Horváth L., Loreto F., Niinemets U., Palmer P.I., Rinne J., Misztal P., Nemitz E., Nilsson D., Pryor S., Gallagher M.W., Vesala T., Skiba U., Brüggemann N., Zechmeister-Boltenstern S., Williams J., O'Dowd C., Facchini M.C., de Leeuw G., Flossman A., Chaumerliac N., Erisman J.W., 2009. Atmospheric composition change: Ecosystems-Atmosphere interactions. Atmospheric Environment 43, 5193-5267.

Gründel M., Porstendörfer J., 2004. Differences between the activity size distributions of the different natural radionuclide aerosols in outdoor air. Atmospheric Environment 38, 3723-3728.

Horvath H., Pesava P., Toprak S., Aksu R., 1996. Technique for measuring the deposition velocity of particulate matter to building surfaces. The Science of the Total Environment 189/190, 255-258.

Jaenicke R., 1988. Aerosol physics and chemistry. In Landolt-Börstein. Numerical data and functional relationships in science and technology, Group V, Vol. 4 Meteorology, subvolume b Physical and chemical properties of the air. Springer-Verlag, Berlin.

Kelly G.N., 1987. The importance of the urban environments for accident consequences. Radiation Protection Dosimetry 21, 13-20. 
Krogstad P.Å., Antonia R.A., 1999. Surface roughness effects in turbulent boundary layers. Experiments in fluids $27,450-460$.

Lai A.C.K., Nazaroff W.W., 2000. Modeling indoor particle deposition from turbulent flow onto smooth surfaces. Journal of Aerosol Science 31, 463-476.

Liu B. Y. H., Agarwal J. K., 1974. Experimental observation of aerosol deposition in turbulent flow. Aerosol Science 5, 145-155.

Maro, D., Connan, O., Hébert, D., Rozet, M., Talbaut, M., Coppalle, A., Sini, J.F., Rosant, J.M., Mestayer, P., Sacré, C., Flori, J.P., Giraud, D., Olive, F., Ruot, B., Roupsard, P., 2010. Quantification of the dry deposition of aerosols in an urban environment: towards a new methodology. International Aerosol Conference 2010, Helsinki.

NF X 44-011, 1972. Séparateurs aérauliques. Méthode de mesure de l'efficacité des filtres au moyen d'un aérosol d'uranine (fluorescéine). AFNOR, La Plaine Saint-Denis.

Papastefanou C., 2006. Residence time of tropospheric aerosols in association with radioactive nuclides. Applied Radiations and Isotopes 64, 93-100.

Papastefanou C., 2008. Radioactivity in the Environment, Volume 12, Chapter 1, Atmospheric Aerosol Particles. Elsevier Science, Oxford.

Pesava P., Aksu R., Toprak S., Horvath H., Seidl S., 1999. Dry deposition of particles to building surfaces and soiling. The Science of the Total Environment 235, 25-35.

Petroff A., Mailliat A., Amielh M, Anselmet F., 2008. Aerosol dry deposition on vegetative canopies. Part II: a new modelling approach and applications. Atmospheric Environment 42, 3654-3683.

Raupach M. R., Antonia R. A., Rajagopalan S., 1991. Rough-wall turbulent boundary layers. Applied Mechanics Reviews 44, 1-25.

Roed J., 1983. Deposition velocity of caesium-137 on vertical building surfaces. Short Communication, Atmospheric Environment 17, 663-664.

Roed J., 1985. Dry deposition of urban surfaces. Ris $\varnothing-R-515$ NKA/REK-1(84)701, Risø National Laboratory, Roskilde. 
401 Roed J., 1987. Dry deposition in rural and in urban areas in Denmark. Radiation Protection Dosimetry 21, $402 \quad 33-36$.

403 Schlichting H., 1968. Boundary-Layer Theory. McGraw Hill, New York.

404 Sehmel G.A., 1980. Particle and gas dry deposition: a Review. Atmospheric Environment 14, 983-1011.

405 Toprak S., Aksu R., Pesava P., Horvath H., 1997. The soiling of materials under simulated atmospheric 406 conditions in a wind tunnel. Journal of Aerosol Science 28, Supplement 1, S585-S586.

407 Van Dingenen R., Raes F., Putaud J.P., Baltensperger U., Charron A., Facchini M.-C., Decesari S., Fuzzi 408 S., Gehrig R., Hansson H.-C., Harrison R.M., Hüglin C., Jones A.M., Laj P., Lorbeer G., Maenhaut W., 409 Palmgren F., Querol X., Rodriguez S., Schneider J., ten Brink H., Tunved P., Tørseth K., Wehner B., 410 Weingartner E., Wiedensohler A., Wåhlin P., 2004. A European aerosol phenomenology - 1: physical 411 characteristics of particulate matter at kerbside, urban, rural and background sites in Europe. 412 Atmospheric Environment 38, 2561-2577.

413 Zhang L., Gong S., Padro J., Barrie L., 2001. A size-segregated particle dry deposition scheme for an 414 atmospheric aerosol module. Atmospheric Environment 35, 549-560. 


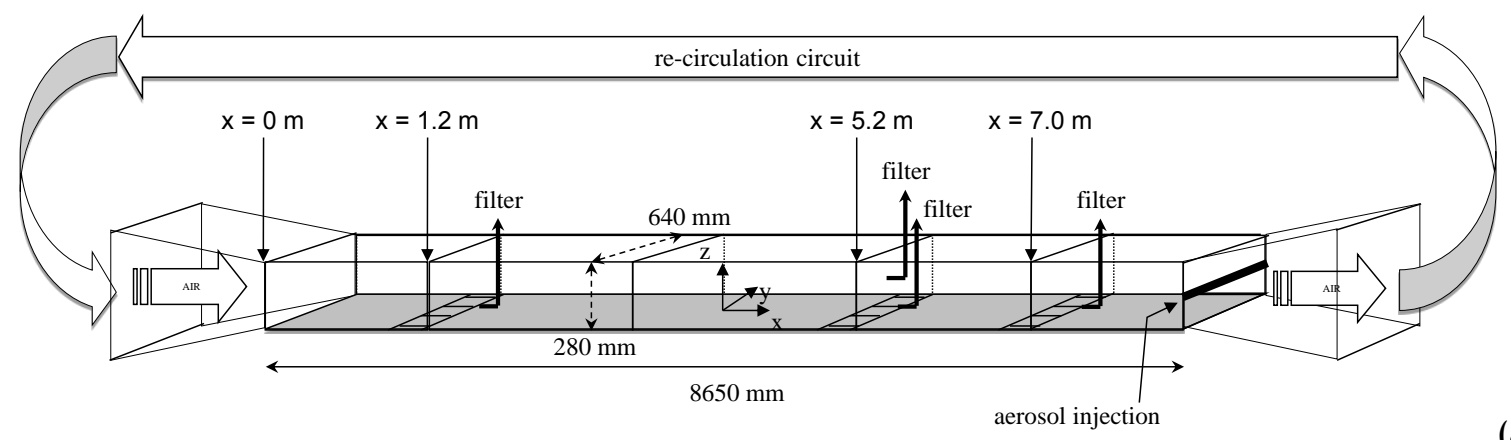

(a)

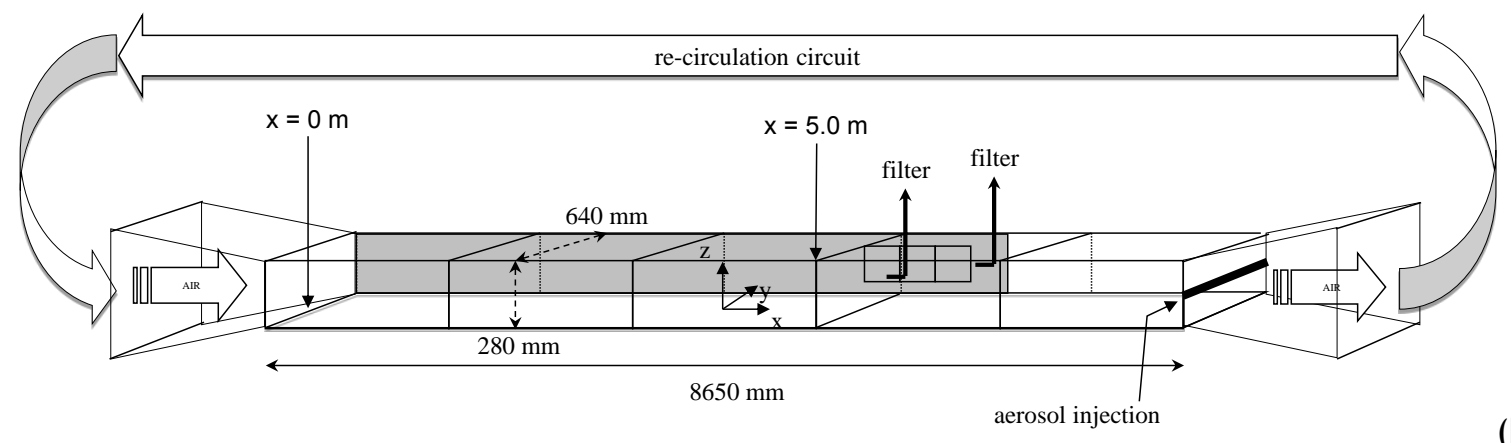

3 Fig. 1: illustrations of the wind tunnel configurations to study deposition on horizontal (a) and vertical (b)

4 walls; the studied surface is grey; the substrates samples are the grey squares.

5

6

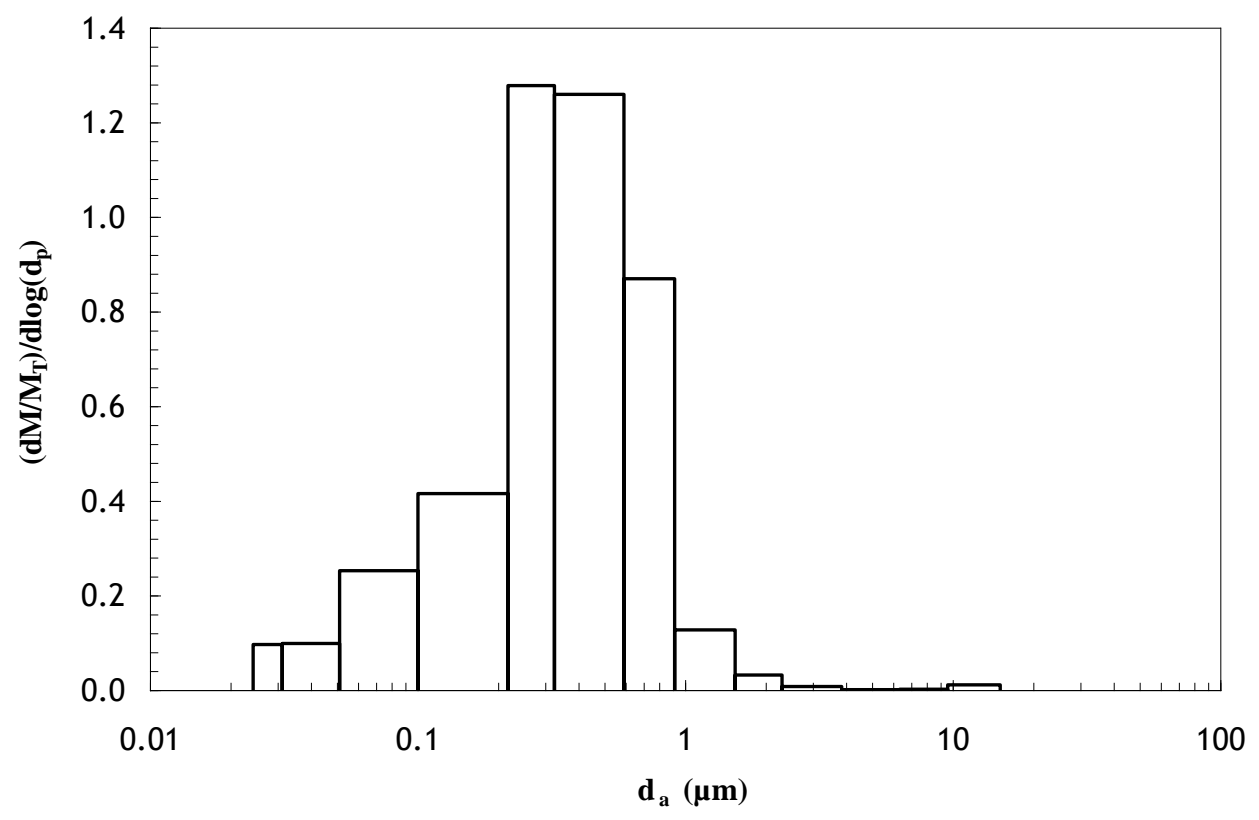

7

8 Fig. 2: normalised granulometric mass distribution of the fluorescein aerosol.

9 


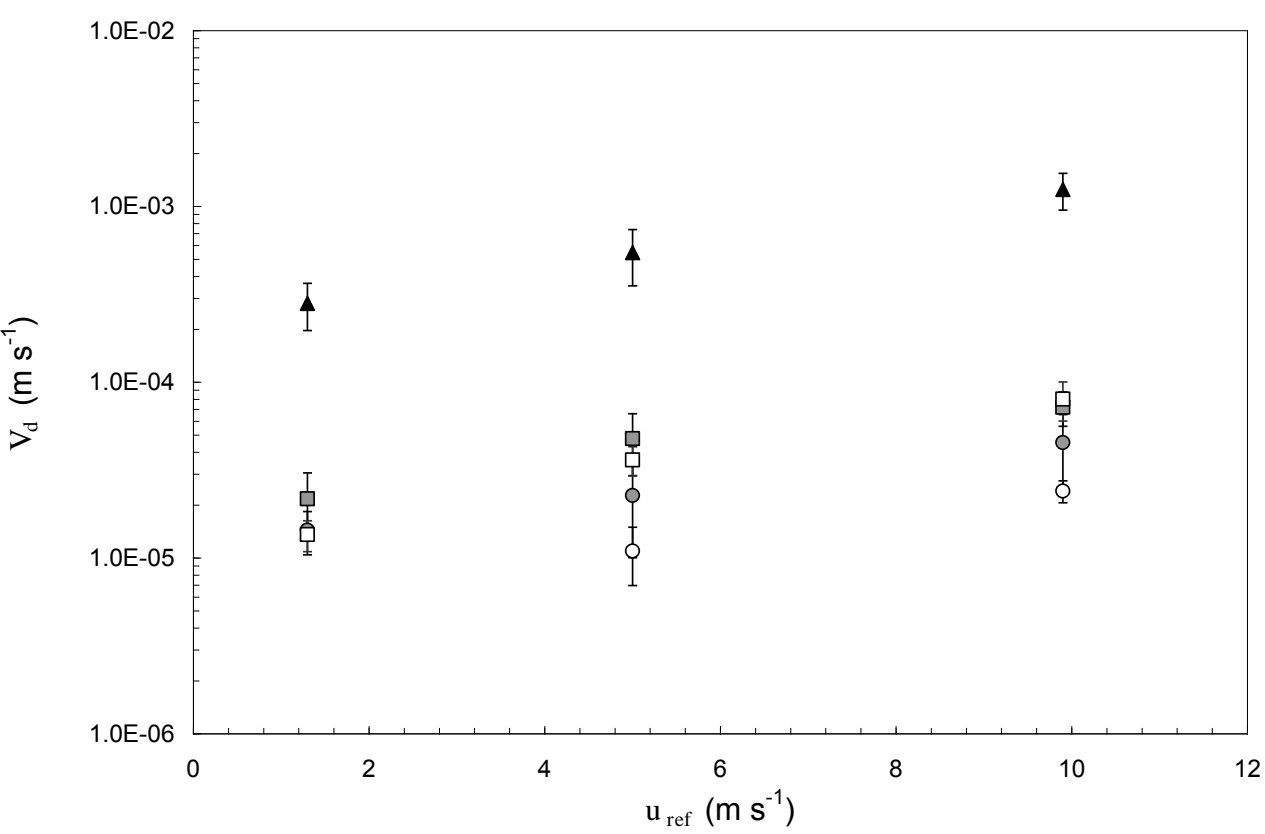

12 Fig. 3: average $V_{d}$ as a function of $u_{\text {ref }}$.

13 O Horizontal conventional glass; O Vertical conventional glass;

$14 \square$ Horizontal cement facing; $\square$ Vertical cement facing;

$15 \Delta$ Synthetic grass.

16

17

18

19

20

21

22

23

24

25 


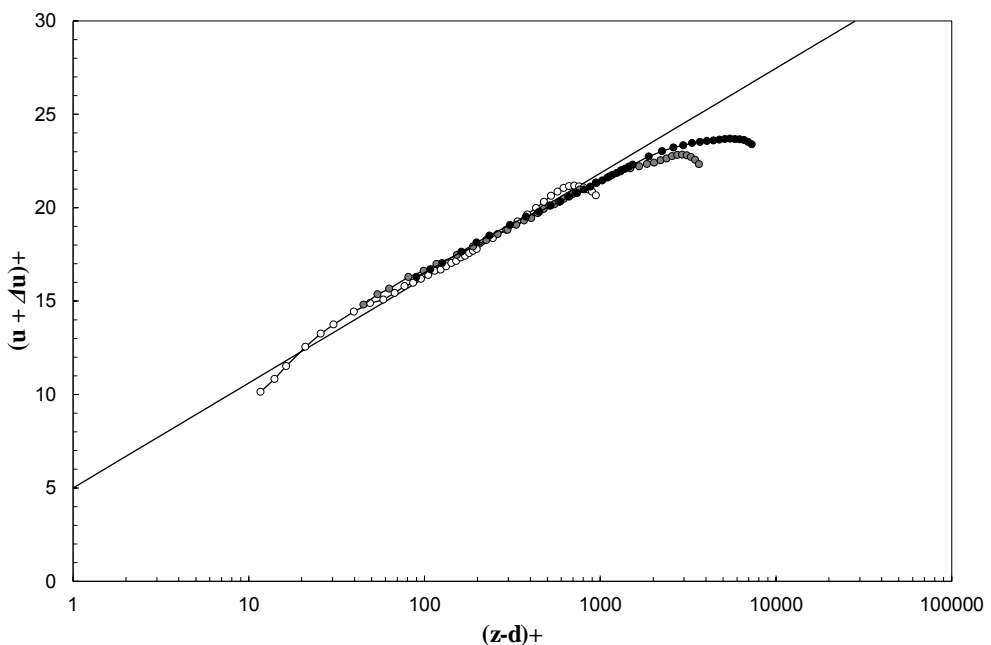

a)

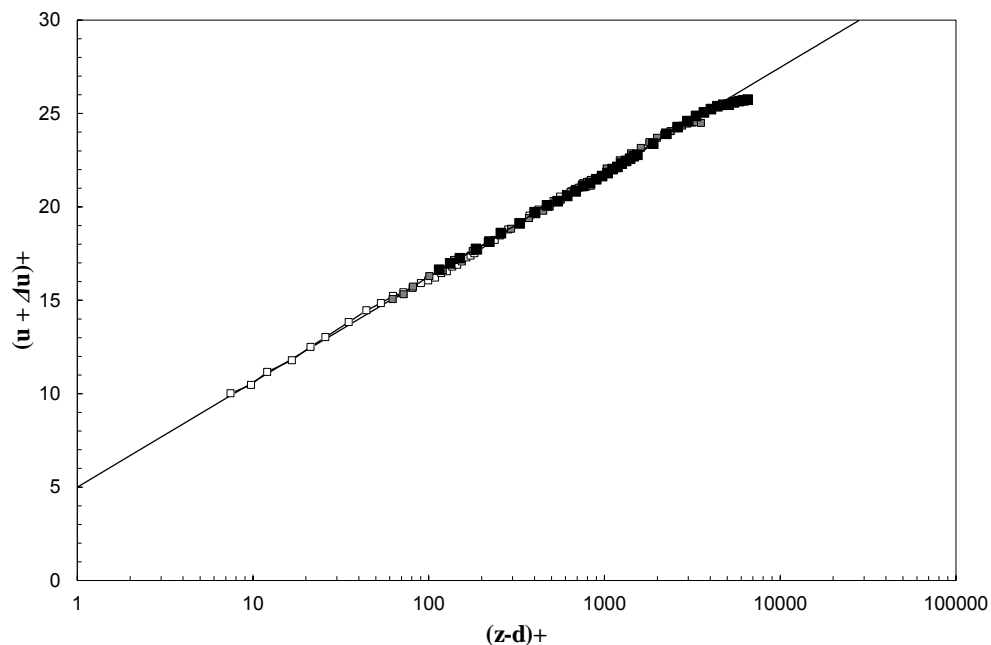

27

b)

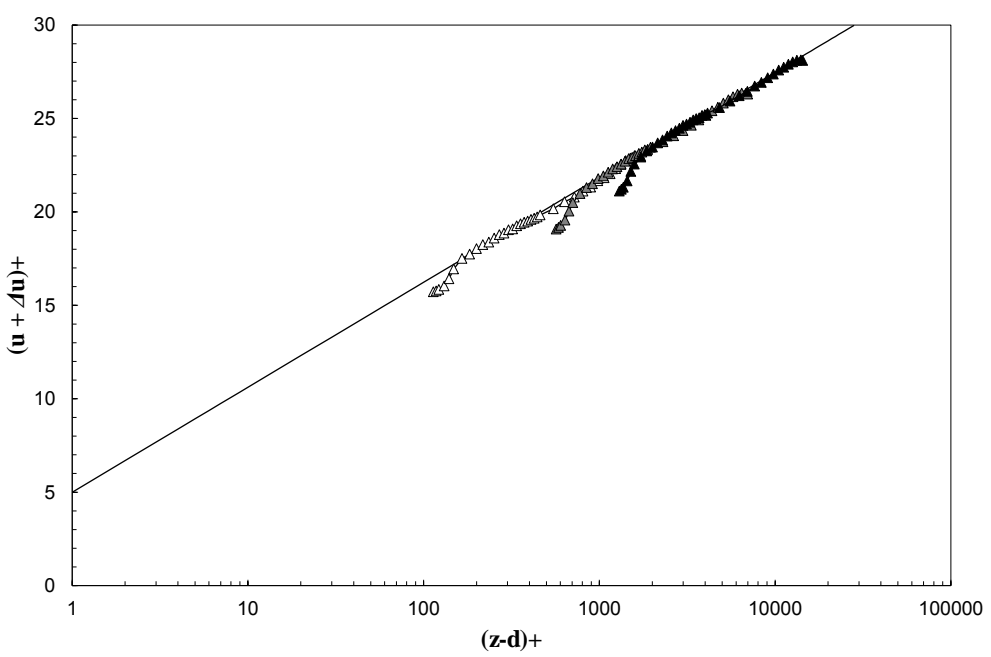

$28 \quad c)$

29 Fig. 4: $\mathrm{u}+$ as a function of $\mathrm{z}+$ for a fetch of $5.10 \mathrm{~m}$ for each type of surface and each $\mathrm{u}_{\mathrm{ref}}$.

a) Conventional glass: $O \mathrm{u}_{\mathrm{ref}}=1.3 \mathrm{~m} \mathrm{~s}^{-1} ; O \mathrm{u}_{\mathrm{ref}}=5.0 \mathrm{~m} \mathrm{~s}^{-1} ; \mathrm{u}_{\mathrm{ref}}=9.9 \mathrm{~m} \mathrm{~s}^{-1}$;

b) Cement facing: $\square \mathrm{u}_{\mathrm{ref}}=1.3 \mathrm{~m} \mathrm{~s}^{-1} ; \square \mathrm{u}_{\mathrm{ref}}=5.0 \mathrm{~m} \mathrm{~s}^{-1} ; \mathrm{u}_{\mathrm{ref}}=9.9 \mathrm{~m} \mathrm{~s}^{-1}$;

c) Synthetic grass: $\Delta u_{r e f}=1.3 \mathrm{~m} \mathrm{~s}^{-1} ; \Delta u_{\text {ref }}=5.0 \mathrm{~m} \mathrm{~s}^{-1} ; \Delta u_{\text {ref }}=9.9 \mathrm{~m} \mathrm{~s}^{-1}$. 


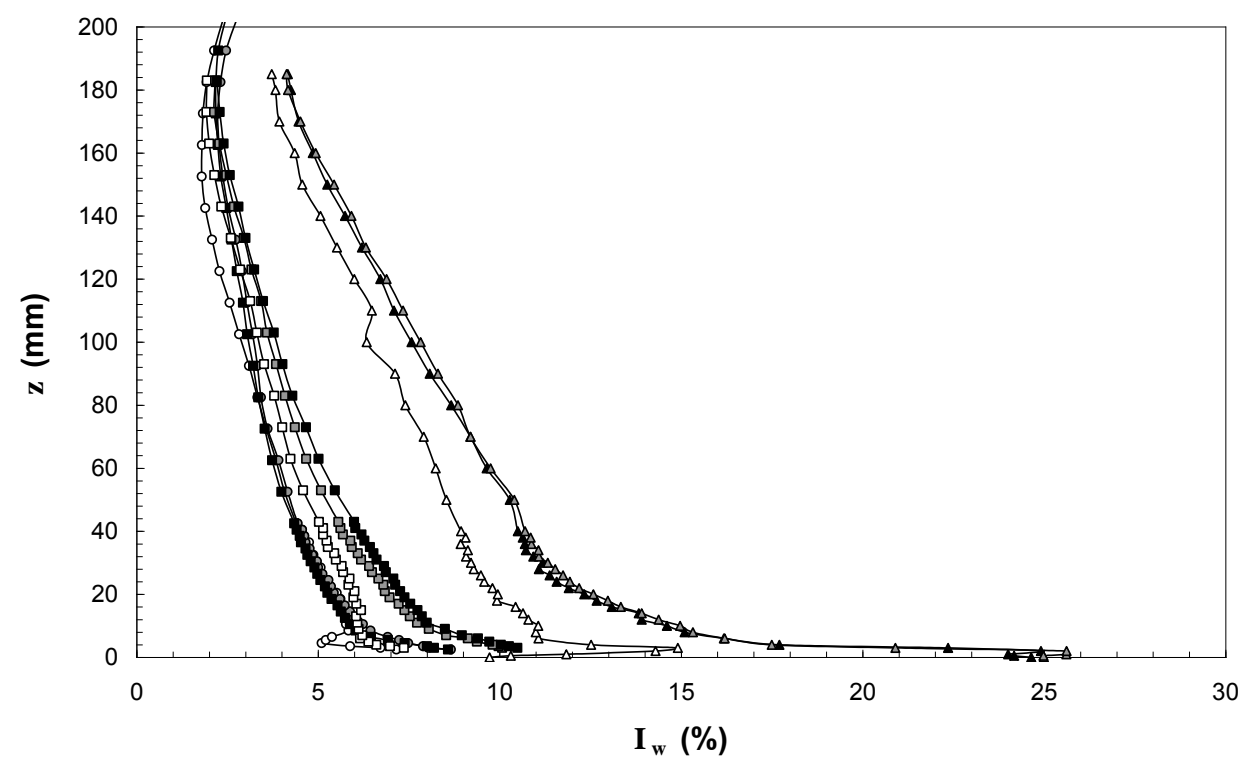

34

Fig. 5: $\mathrm{I}_{\mathrm{w}}$ as a function of $\mathrm{z}$ for a fetch of $5.10 \mathrm{~m}$, for each surface type and each $\mathrm{u}_{\mathrm{ref}}$.

Conventional glass: $O \mathrm{u}_{\mathrm{ref}}=1.3 \mathrm{~m} \mathrm{~s}^{-1} ; \circ \mathrm{u}_{\mathrm{ref}}=5.0 \mathrm{~m} \mathrm{~s}^{-1} ; \mathrm{u}_{\mathrm{ref}}=9.9 \mathrm{~m} \mathrm{~s}^{-1}$;

Cement facing: $\square \mathrm{u}_{\mathrm{ref}}=1.3 \mathrm{~m} \mathrm{~s}^{-1} ; \square \mathrm{u}_{\mathrm{ref}}=5.0 \mathrm{~m} \mathrm{~s}^{-1} ; \mathrm{u}_{\mathrm{ref}}=9.9 \mathrm{~m} \mathrm{~s}^{-1}$;

Synthetic grass: $\Delta u_{\text {ref }}=1.3 \mathrm{~m} \mathrm{~s}^{-1} ; \Delta u_{\text {ref }}=5.0 \mathrm{~m} \mathrm{~s}^{-1} ; \Delta u_{\text {ref }}=9.9 \mathrm{~m} \mathrm{~s}^{-1}$.

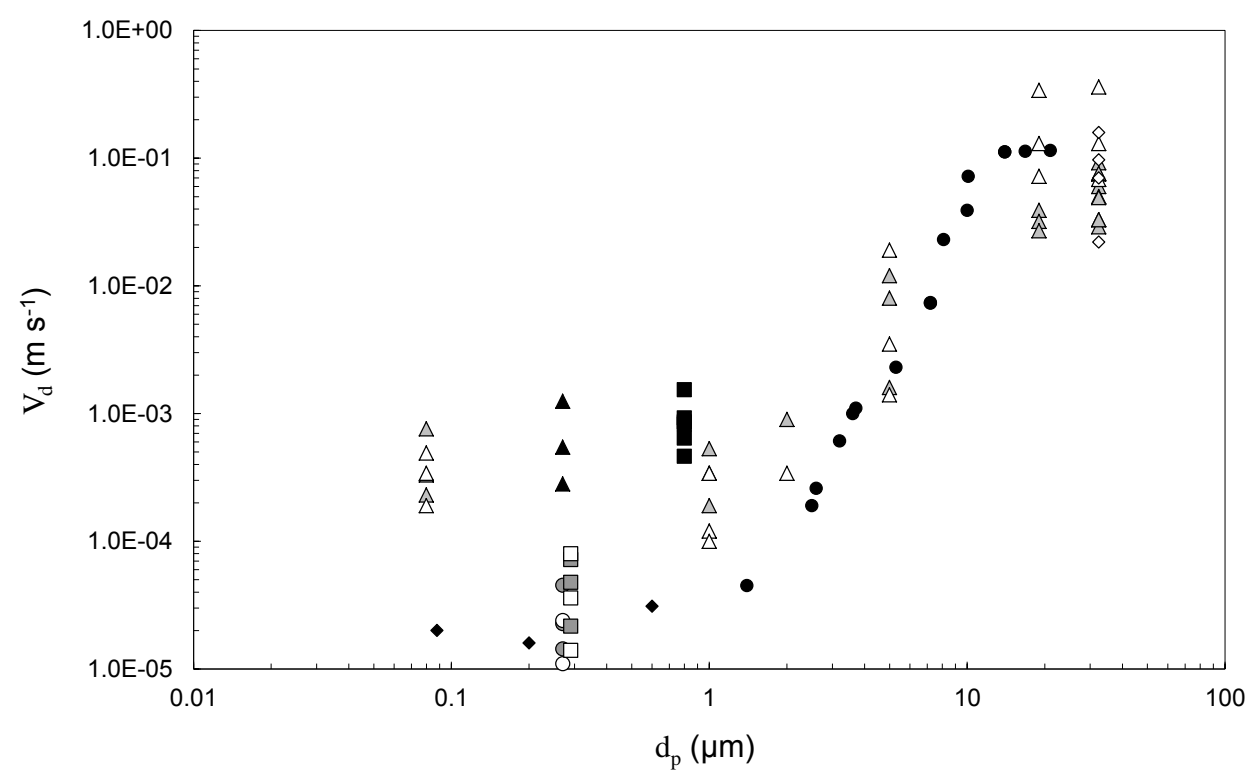

Fig. 6: mean $V_{d}$ of this study and $V_{d}$ from the literature as a function of $d_{p}$.

- Vertical glass (Liu and Agarwal, 1974); $\diamond$ Glass (Horvath et al. ,1996); $\diamond$ horizontal sticky rough glass (Chamberlain, 1967); - Cement (Toprak et al., 1997); $\Delta$ Sticky artificial grass, $\Delta$ Real grass (Chamberlain, 1967);

This study: O Horizontal conventional glass; O Vertical conventional glass;

$\square$ Horizontal cement facing; $\square$ Vertical cement facing;

$\Delta$ Synthetic grass. 


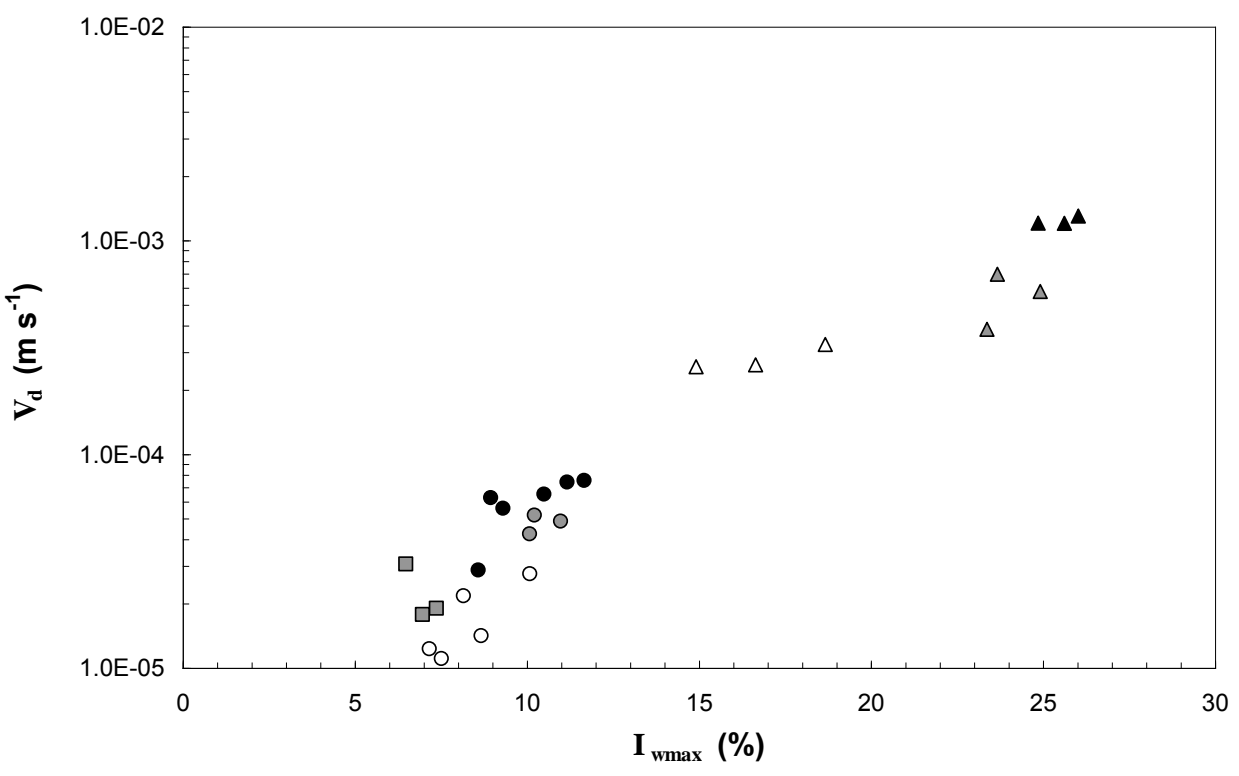

Fig. 7: average $V_{d}$ as a function of $I_{w m a x}$ for each type of surface.

Conventional glass: $O \mathrm{u}_{\mathrm{ref}}=1.3 \mathrm{~m} \mathrm{~s}^{-1} ; O \mathrm{u}_{\mathrm{ref}}=5.0 \mathrm{~m} \mathrm{~s}^{-1} ; \bullet \mathrm{u}_{\mathrm{ref}}=9.9 \mathrm{~m} \mathrm{~s}^{-1}$;

Cement facing: $\square \mathrm{u}_{\mathrm{ref}}=1.3 \mathrm{~m} \mathrm{~s}^{-1} ; \square \mathrm{u}_{\mathrm{ref}}=5.0 \mathrm{~m} \mathrm{~s}^{-1} ; \mathrm{u}_{\mathrm{ref}}=9.9 \mathrm{~m} \mathrm{~s}^{-1}$;

Synthetic grass: $\Delta u_{\mathrm{ref}}=1.3 \mathrm{~m} \mathrm{~s}^{-1} ; \Delta \mathrm{u}_{\mathrm{ref}}=5.0 \mathrm{~m} \mathrm{~s}^{-1} ; \Delta \mathrm{u}_{\mathrm{ref}}=9.9 \mathrm{~m} \mathrm{~s}^{-1}$.

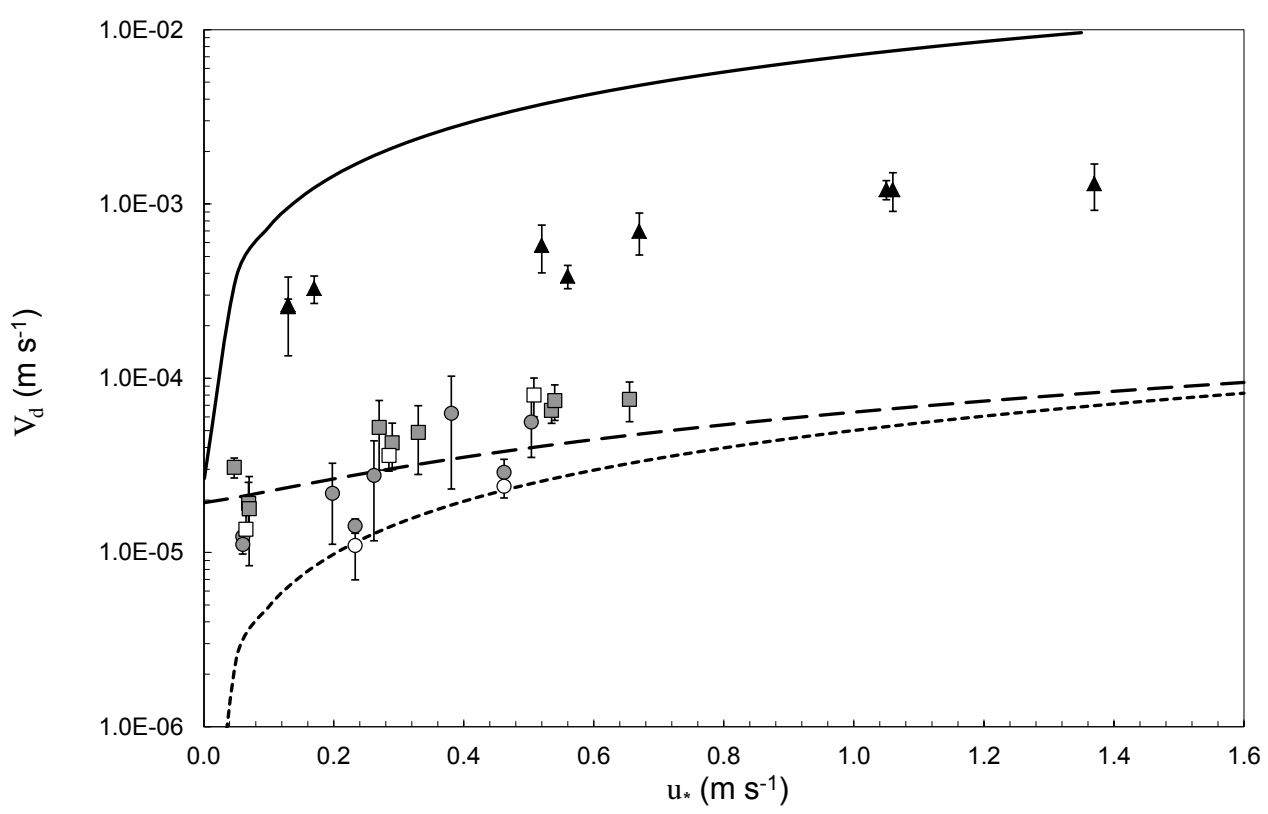

52

Fig. 8: $\mathrm{V}_{\mathrm{d}}$ as a function of $\mathrm{u}_{*}$, comparison of model to measurements.

- - - Horizontal smooth wall, - - - Vertical smooth wall (Lai and Nazaroff, 2000);

_ Grass (Zhang et al., 2001);

This study: O Horizontal conventional glass; O Vertical conventional glass;

$\square$ Horizontal cement facing; $\square$ Vertical cement facing;

$\Delta$ Synthetic grass. 


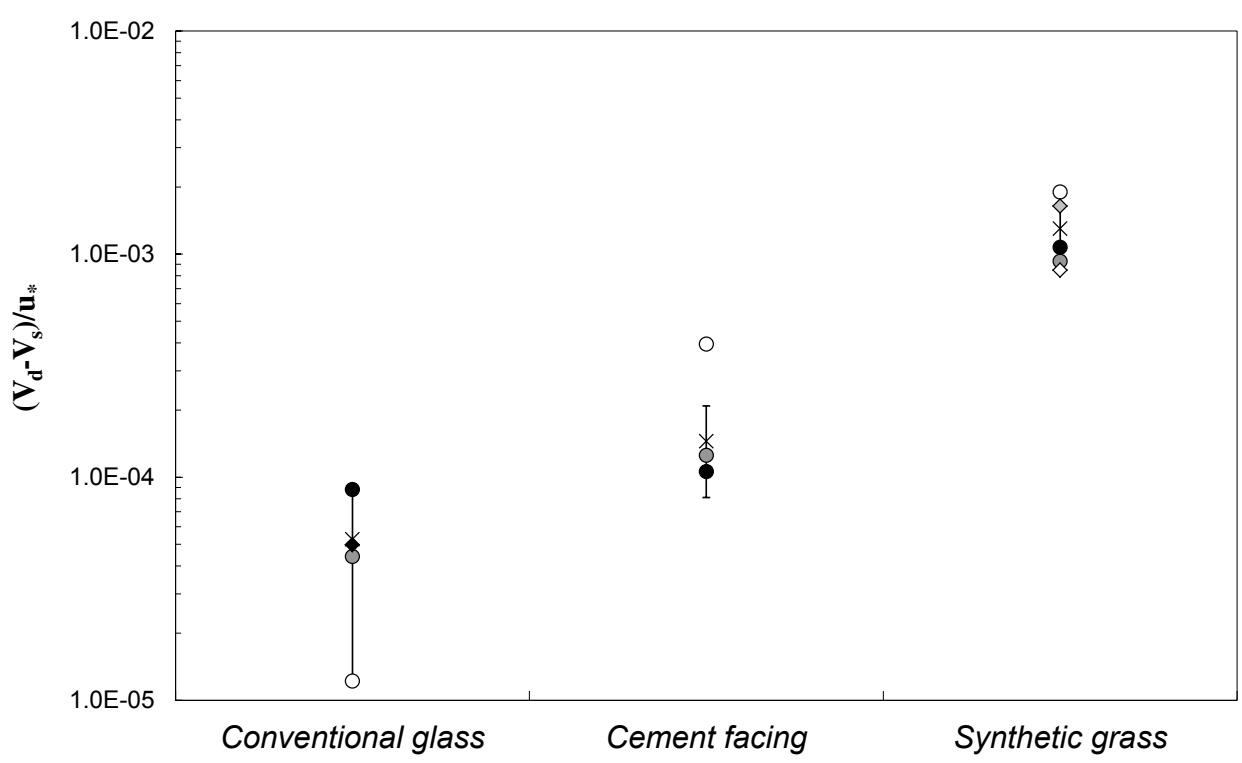

60 Fig. 9: $\frac{V_{d}-V_{s}}{u_{*}}$ ratios for each type of horizontal surface.

61

- Smooth wall (Lai and Nazaroff, 2000);

$62 \diamond \operatorname{Grass}\left(\mathrm{d}_{\mathrm{p}}=0.202 \mu \mathrm{m}\right), \diamond \operatorname{Grass}\left(\mathrm{d}_{\mathrm{p}}=0.316 \mu \mathrm{m}\right)($ Damay, 2010);

63 This study: $O \mathrm{u}_{\mathrm{ref}}=1.3 \mathrm{~m} \mathrm{~s}^{-1} ; O \mathrm{u}_{\mathrm{ref}}=5.0 \mathrm{~m} \mathrm{~s}^{-1} ; \bullet \mathrm{u}_{\mathrm{ref}}=9.9 \mathrm{~m} \mathrm{~s}^{-1} ; \mathrm{x}$ mean on all $\mathrm{u}_{\mathrm{ref}}$ for each surface. 